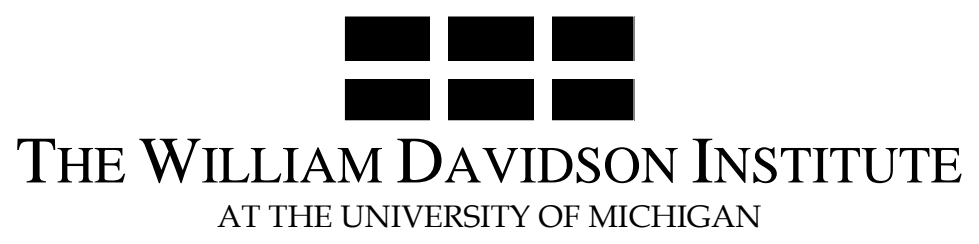

AT THE UNIVERSITY OF MICHIGAN

\title{
Anthropometry of Love Height and Gender Asymmetries in Interethnic Marriages
}

\author{
By: Michèle Belot and Jan Fidrmuc
}

William Davidson Institute Working Paper Number 950 January 2009 


\title{
Anthropometry of Love Height and Gender Asymmetries in Interethnic Marriages*
}

\author{
Michèle Belot ${ }^{\dagger}$ and Jan Fidrmuc ${ }^{\ddagger}$ \\ Nuffield College (Oxford University) and Brunel University
}

January 16, 2009

\begin{abstract}
Both in the UK and in the US, we observe puzzling gender asymmetries in the propensity to outmarry: Black men are substantially more likely to have white spouses than Black women, but the opposite is true for Chinese: Chinese men are half less likely to be married to a White person than Chinese women. We argue that differences in height distributions, combined with a simple preference for a taller husband, can explain a large proportion of these ethnic-specific gender asymmetries. Blacks are taller than Asians, and we argue that this significantly affects their marriage prospects with whites. We provide empirical support for this hypothesis using data from the Health Survey for England and the Millenium Cohort Study, which contains valuable and unique information on heights of married couples.
\end{abstract}

Keywords: Intermarriage, gender, height

JEL codes: J12, J15

\footnotetext{
${ }^{*}$ We have benefited from helpful comments and suggestions by Jan van Ours, David Reinstein, V. Bhaskar, Robert Pollak, Steve Pudney as well as seminar participants at Brunel University, Charles University, Jyväskyllä and at WPEG conference in Sheffield.

${ }^{\dagger}$ Centre for Experimental Social Sciences, Nuffield College, Oxford University, Email: Michele.Belot@nuffield.ox.ac.uk, Phone: +44 1865278548.

${ }^{\ddagger}$ Department of Economics and Finance, and Centre for Economic Development and Institutions (CEDI), Brunel University, Uxbridge, UB8 3PH, UK. Email: Jan.Fidrmuc@brunel.ac.uk or jan@fidrmuc.net. Phone: +44-1895-266-528. Web: http://www.fidrmuc.net/.
} 


\section{Introduction}

Interethnic marriages exhibit puzzling ethnic-specific gender asymmetries. Both in the UK and the US, black women are much less likely to have a white spouse than black men while the pattern is exactly reversed for East-Asians, in particular Chinese. ${ }^{1}$ In the UK, Black Caribbean men are 50 percent more likely to have a white spouse than Black Caribbean women: 22 percent Black Carribean men intermarry with whites, compared to 15 percent of Black Carribean women. On the other hand, Chinese men are half as likely to have a white spouse than Chinese women: the rates of intermarriage with whites are 9 percent for Chinese men and 17 percent for Chinese women. A very similar pattern is observed in the US as well where Black men and Asian women are more than two to three times more likely to have a white spouse than their counterparts of the opposite gender ${ }^{2}$

Interethnic marriages are usually considered as the ultimate symbol of social integration. A number of studies show that intermarriage has important implications for the social mobility of ethnic minorities in Western societies. For example, Meng and Gregory (2005) and Meng and Meurs (2006), argue that immigrants who intermarry have higher earnings on average than endogamous immigrants. ${ }^{3}$ Van Ours and Veenman (2008) similarly find that children from mixed marriages attain higher education. To this date, however, there is little understanding of the forces driving intermarriage; and even less of those driving gender differences in intermarriage within the same race. Fryer (2007) shows that patterns of intermarriage across ethnicities and gender are hard to explain with the existing theories. For example, Merton's social exchange theory (1941) predicts that men and women from ethnic minorities who intermarry should have better socio-economic characteristics than those who marry within their own ethnicity.

\footnotetext{
${ }^{1}$ Moreover, this seems to apply not only to marriages but also to sexual intimacy. Sailer (1997), for example, observes that white women are much more likely to mention that their last sexual partner was black than white men.

${ }^{2}$ These figures are based on the UK 2001 and US 2006 census, respectively. More detailed figures, also for other ethnic groups, are reported in Tables 1-4 below.

${ }^{3}$ Meng and Gregory and Meng and Meurs argue that their results are robust to possible endogeneity of intermarriage. Kantarevic (2004), however, undermines their findings, arguing that the higher earnings of intermarried immigrants can be ascribed largely to self-selection of immigrants into intermarrying.
} 
However, the data show that black men who intermarry tend to be less educated than those who intramarry and black women are generally more educated than black men yet is it the black men who are more likely to intermarry with whites.

One possible explanation is that men and women from the same ethnic group have different preferences for, or are more or less open to, outmarriage. For example, one hypothesis commonly advanced in the popular press is that South-Asians (especially Pakistani and Bangladeshi) are more tolerant towards outmarriage of men than of women. However, there is little evidence (whether direct or anecdotal) that the same asymmetry holds for blacks and East-Asians, although that is where we observe particularly large gender-specific differences in intermarriage.

We propose a different, and simpler, explanation for these ethnic-specific gender asymmetries. We argue that a simple preference for a taller husband (or shorter wife) can explain part of the gender-specific asymmetries across ethnic groups in the propensity to outmarry. Blacks are taller than Asians, and their height distribution is closer to whites. Because they are taller, black men have better prospects on the white marriage market than Asian men. For women, the reverse is true. Because Asians are relatively short on average, women fare substantially better on the white marriage market than Black women. ${ }^{4}$

We present evidence supporting a "male-superior norm" (a norm requiring the husband's attribute to be superior or equal to the wife's attribute) as pertaining to height. One could argue that the "male-superior norm" may even be more salient among ethnic minorities which frequently espouse more conservative (or traditional) socio-cultural norms than the majority white population (especially in areas of marriage and intimacy). An interesting implication of such a norm is that, combined with a positive correlation in attributes between men and women of same ethnicity (that is, men and women from a given ethnic group tend compare similarly to other ethnic groups), it will generate gender asymmetries in intermarriage. Besides height, we consider also whether the "male-superior" norm applies similarly along another dimension:

\footnotetext{
${ }^{4}$ This hypothesis has actually been mentioned in the popular press (see Sailer, 1997).
} 
education.

We first present a descriptive analysis using data from the UK Census 2001 and the Labour Force Survey.We find that Asian men in exogamous relationships tend to be positively selected along socio-economic attributes, while Blacks are negatively selected. Also, we find that Asian women tend to attract white husbands with favorable socio-economic attributes, more so than Black Caribbean women. These findings point at an asymmetry beyond standard socio-economic characteristics determining the relative attractiveness of men and women of these different ethnic groups. We argue that height could be the missing attribute underlying this asymmetry.

We then investigate empirically the extent to which a "male-superior" norm along the educational and height dimensions explains the ethnic-specific gender asymmetries. We use data from two main sources: one is the Health Survey for England, which is a large survey carried out among British households oversampling ethnic minorities. The data set includes individual information of socio-economic characteristics and, crucially, heigh. The downside is that the number of inter-ethnic marriages is limited. Therefore, we utilize another data set, the Millenium Cohort Survey (MCS), which also includes detailed individual information on socio-economic characteristics and height. The MCS has a larger share of intermarriages. Moreover, as the respondents in the survey are parents of babies born in the year 2000, the data by construction capture a sample of long-term relationships. We first calculate the proportion of acceptable partners corresponding to each ethnic group and gender. Then, we examine the extent to which these proportions of acceptable partners explain intermarriage. We show that height does a much better job at explaining gender asymmetries than education.

The paper is organised as follows. We first review the literature in Section 1 . Section 2 presents summary statistics on intermarriage in the UK and the US, as well as descriptive statistics of the ethnic groups in terms of population share and education distribution. Section 3 discusses a simple model of asymmetric gender preferences and discuss the empirical implications. Section 4 presents an empirical analysis based on the UK labour force survey. Section 5 
discusses the implications of asymmetric preferences and presents evidence of the importance of the "height-rule" using the Millenium Cohort Study. Finally we conclude in Section 5.

\section{Theories of intermarriage}

Interethnic marriages have been studied extensively in sociological literature and, more recently, in economics. The seminal theory in sociology is Merton's (1941) exchange theory. ${ }^{5}$ The basic idea is that marrying across the racial line is costly to whites but brings benefits to the ethnic-minority individuals. This is so because whites, being the majority, enjoy a higher social status. In turn, gender differences in outmarriage rates could come from different abilities of men and women from the same minority ethnic group to compensate for their "inferior" social status. Traditionally, black men were in a better position to do so, by being more likely to be employed and by possessing higher education and/or skills. Women, on the other hand, used to be mostly out of the labour force (at least at the time he proposed his theory). This explanation, however, fails to explain why East-Asian men are less likely than East-Asian women to intermarry with whites and why the gender asymmetry in the rates of intermarriage of blacks persists despite increasing labor-force participation of women and despite black women currently attaining higher education than black men.

The economic theories of marriage go back to the seminal insights of Becker $(1973,1974)$. Becker models marriage as an equilibrium outcome in which the spouses maximize their wellbeing which, crucially, includes consumption of household or relationship specific goods that cannot be purchased in the market - such as love, companionship, producing and raising children and so on. In the original work, utility is perfectly transferable such that the equilibrium on the marriage market maximizes the aggregate marital output. A key issue in Becker's analysis is whether the spouses' inputs (or characteristics) are complements or substitutes. If they are complements, then the market will generate positive sorting (marriage of 'likes'), if they

\footnotetext{
${ }^{5}$ See the detailed discussion of Merton's exchange theory as well as some other explanations of interethnic marriage by Jacobs and Labov (2002).
} 
are substitutes, the market will generate negative sorting. In the context of ethnicity or race, one could argue that the inteherent heterogeneity of mixed marriages may generate positive returns to the spouses and their children, for example, by equiping them with additional linguistic skills or by helping them integrate (as argued above). On the other hand, the cultural (and especially religious) and linguistic differences between the spouses may lower their utility from marriage and therefoer may come at a cost.

The literature has also identified various systematic patterns attitudes and preferences regarding traits of potential partners. Given that marriage is an equilibrium outcome, it is challenging to identify the preferences driving the equilibrium. A few recent papers have used actual choices in a dating setting to shed light on the mechanisms driving the choice of a partner (see Fisman et al., 2006, 2008, Hirtsch, Hortacsu and Ariely, 2006, 2008, and Belot and Francesconi, 2006). The evidence suggests that people prefer a partner of similar age, educational background, ethnicity and culture, and both men and women prefer the man to be taller than the woman. Fisman et al. (2006) find some support for the "male-superior" norm along the intelligence and ambition dimensions. They find that a man's demand for intelligence and ambition does not extend to women who are more intelligent or ambitious than he is. In fact, a man is significantly less likely to accept a woman who is more ambitious than he.

The "male-superior" norm also receives support in Higgins et al. (2002). They carried out surveys among university students in the UK and China on preferences with respect to age, education and height of one's potential spouse. They find that both Chinese and UK students are much more likely to express preferences stipulating that "husband should be taller" and "husband should be older": 92 percent of Chinese female students and 78 percent of British females prefer a taller partner and 72 percent of Chinese women prefer him to be older compared to 44 percent for UK females. These preferences are also present among men, although to a lesser extent: 50 percent of Chinese males prefer their partner to be shorter and 45 want a younger partner, compared with 43 and 14 percent, respectively, of UK males. Along the education dimension, most women prefer a husband who is at least as educated as themselves 
(this is true for $63 \%$ of British women and $71.6 \%$ of Chinese women) and Chinese men also have preference for a partner that is at most as educated as them (62.3\%). British men either do not care $(50.6 \%)$ or prefer someone with the same or higher level of education $(40.2 \%$ and $7.9 \%$ respectively). These findings suggest that, first, the "male-superior" norm seems to be more present along the height dimension than the education dimension and, second, the norm is possibly more present among ethnic minorities than among British whites.

To date, that there is very little work attempting to explain ethnic-specific gender asymmetries (although those have been noted repeatedly in the literature). One exception is a paper by Jabobs and Labov (2002), who argue that war brides explain part of the gender asymmetry in intermarriage rates in the US: some of the East-Asian women married to whites are the wives of ex-servicemen stationed in Japan and Korea. Once they control for this effect, the differences in intermarriage rates across ethnicities shrink but do not disappear. Thus, the existence of war brides seems to be only part of the puzzle. Furthermore, war brides are likely to play little role in explaining the patterns of intermarriage in the UK.

\section{Interethnic marriages in the UK and the US}

\subsection{Descriptive statistics using census data}

Interethnic marriages are generally a rare occurence. Despite the increasing heterogeneity of modern Western societies such as the UK, endogamy is still largely the rule ${ }^{6}$. According to the UK 2001 census (see Tables 1-2), 97 percent of white British men and women had a spouse of the same ethnicity (the share of endogamous marriages is even higher, 98 percent, if white British and white Irish are counted as a single group and 99 percent if all whites are taken together). Among ethnic minorities, similarly, endogamy is the predominant pattern. ${ }^{7}$ This is especially the case for South-Asians, with between 91 and 95 percent of their marriages being

\footnotetext{
${ }^{6}$ This holds not only for interethnic marriage but, as documented by Bisin et al. (2004), also for religious intermarriage.

${ }^{7}$ Nevertheless, in the UK at present, 'mixed race' is the fastest-growing ethnic category, although this can be driven by greater propensity of mixed-ancestry individuals to report their ethnicity as 'mixed' instead of choosing the ethnicity of one of the parrents.
} 


\begin{tabular}{|c|c|c|c|c|c|c|c|c|}
\hline \multirow[b]{2}{*}{$\begin{array}{l}\text { Female } \\
\text { ethnicity }\end{array}$} & \multicolumn{8}{|c|}{ Male ethnicity } \\
\hline & $\begin{array}{l}\text { White } \\
\text { British }\end{array}$ & $\begin{array}{l}\text { White } \\
\text { Irish }\end{array}$ & Indian & Pakist. & Bangl. & $\begin{array}{l}\text { Black } \\
\text { Carib. }\end{array}$ & $\begin{array}{l}\text { Black } \\
\text { African }\end{array}$ & Chinese \\
\hline White Brit. & 96.58 & 56.15 & 4.53 & 3.47 & 2.06 & 22.13 & 10.11 & 9.07 \\
\hline White Irish & 0.91 & 38.67 & 0.33 & 0.18 & 0.10 & 0.81 & 0.57 & 0.50 \\
\hline Indian & 0.11 & 0.29 & 91.56 & 1.48 & 0.95 & 0.53 & 0.73 & 0.27 \\
\hline Pakist. & 0.03 & 0.05 & 0.72 & 91.66 & 0.70 & 0.11 & 0.53 & 0.10 \\
\hline Bangl. & 0.01 & 0.01 & 0.20 & 0.26 & 94.56 & 0.03 & 0.06 & 0.07 \\
\hline Bl. Carib. & 0.10 & 0.24 & 0.11 & 0.07 & 0.05 & 67.53 & 4.53 & 0.10 \\
\hline Bl. African & 0.05 & 0.16 & 0.11 & 0.20 & 0.08 & 1.62 & 76.31 & 0.04 \\
\hline Chinese & 0.11 & 0.21 & 0.11 & 0.06 & 0.07 & 0.12 & 0.11 & 85.98 \\
\hline All & 100 & 100 & 100 & 100 & 100 & 100 & 100 & 100 \\
\hline
\end{tabular}

endogamous.

For the remaining groups, we observe striking gender-specific differences in the propensity to intermarry. Black women are more likely to be in endogamous marriages than the males of the same group: 75 and 82 percent of black Caribbean and black African women, respectively, have a spouse of the same ethnicity whereas the same holds only for 68 and 76 percent of black Caribbean and black African men. The opposite pattern prevails among Chinese: 71 percent of women have a Chinese husband, compared with 86 percent of men who have a Chinese wife. Exogamy figures illustrate the dramatic differences in propensities to marry out across genders even better: 23 percent of Chinese women in the UK have a white British husband, compared with 9 percent of Chinese men who have a white British wife. Hence, a Chinese woman is more than twice as likely to marry a white person than a Chinese man. The diffences in exogamy for blacks are less dramatic but still substantial. The rates of exogamous marriage with ethnic groups other than whites are much smaller, except for black Africans and black Caribbeans marrying each other or other blacks or blacks marrying a person of mixed white/black ancenstry (to conserve space, figures for mixed races and for other blacks are not reported in Tables 1-2).

US statististics are similar (see Tables 3-4). Again, most whites, 98 percent, live in en- 


\begin{tabular}{|c|c|c|c|c|c|c|c|c|}
\hline \multirow[b]{2}{*}{$\begin{array}{l}\text { Male } \\
\text { ethnicity }\end{array}$} & \multicolumn{8}{|c|}{ Female ethnicity } \\
\hline & $\begin{array}{l}\text { White } \\
\text { British }\end{array}$ & $\begin{array}{l}\text { White } \\
\text { Irish }\end{array}$ & Indian & Pakist. & Bangl. & $\begin{array}{l}\text { Black } \\
\text { Carib. }\end{array}$ & $\begin{array}{l}\text { Black } \\
\text { African }\end{array}$ & Chinese \\
\hline White Brit. & 97.20 & 57.69 & 4.24 & 1.95 & 1.31 & 15.30 & 9.51 & 22.81 \\
\hline White Irish & 0.85 & 36.92 & 0.18 & 0.06 & 0.03 & 0.55 & 0.45 & 0.66 \\
\hline Indian & 0.11 & 0.53 & 91.27 & 1.32 & 1.01 & 0.43 & 0.51 & 0.58 \\
\hline Pakist. & 0.05 & 0.16 & 0.82 & 93.06 & 0.70 & 0.15 & 0.52 & 0.19 \\
\hline Bangl. & 0.01 & 0.03 & 0.19 & 0.26 & 94.62 & 0.04 & 0.08 & 0.07 \\
\hline Bl. Carib. & 0.16 & 0.37 & 0.15 & 0.06 & 0.04 & 74.63 & 2.22 & 0.19 \\
\hline Bl. African & 0.06 & 0.21 & 0.17 & 0.22 & 0.07 & 3.94 & 82.11 & 0.13 \\
\hline Chinese & 0.04 & 0.12 & 0.04 & 0.03 & 0.05 & 0.06 & 0.03 & 71.22 \\
\hline All & 100 & 100 & 100 & 100 & 100 & 100 & 100 & 100 \\
\hline
\end{tabular}

\begin{tabular}{|c|c|c|c|c|}
\hline & Male e & nnicity & & \\
\hline Female ethnicity & White & Asian & Black & Other \\
\hline White & 97.80 & 6.48 & 6.61 & 46.24 \\
\hline Asian & 1.03 & 92.81 & 0.79 & 3.54 \\
\hline Black & 0.23 & 0.22 & 91.57 & 1.99 \\
\hline Other & 0.94 & 0.48 & 1.04 & 48.23 \\
\hline All & 100 & 100 & 100 & 100 \\
\hline
\end{tabular}

dogamous marriages. Black men and Asian women are more likely to intermarry with whites than their ethnic counterparts of the opposite gender. Specifically, 96 percent of black women have endogamous marriages compared with 92 percent of black males, and 80 percent of Asian women versus 93 percent of Asian men. Again, the disparity is especially striking for Asians: with 17 percent of Asian women married to whites, they are almost three times more likely than Asian males to intermarry with whites.

The populations of the various ethnic groups in the UK differ not only in their relative weights within the British society but also in their composition and average socio-economic characteristics, as Table 5 illustrates. The gender composition of the different ethnic groups varies substantially. For white Brits, women outnumber men by 8 percent (considering only 


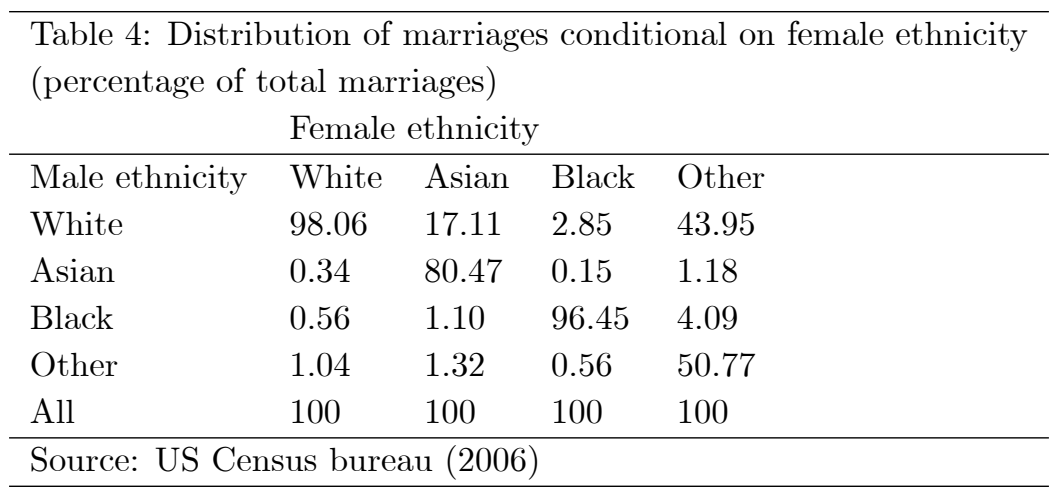

those aged 16 and over). For some ethnic minorities such as blacks, the female/male ratio is much higher; this is especially the case of black Caribbeans and other blacks. On the other hand, the populations of Pakistanis, Bangladeshis and especially other Asians have an excess of males. The Chinese, finally, differ little from the whites in their female/male ratio.

The various ethnic groups differ also with respect to their socio-economic attributes such as education. Among non-white ethnic groups, Chinese and Indians have the highest educational attainement, while Pakistani, Bangladeshi and Black Caribbeans are at the bottom of the distribution. There is a notable difference between Black Africans and Black Caribbeans, the former being twice more likely to hold a university degree than the latter (for males). It is notable, however, that there is a clear correlation in educational attainments across genders within the same ethnicity.

Based on these numbers and in light of the theories put forward by Becker and Merton, we should expect black Caribbean women to display a higher propensity to intermarry with whites than their ethnic male counterparts: there is an excess of black Caribbean women in the UK and they are also more educated on average than black Caribbean men. We should similarly expect Indian, Pakistani and Bangladeshi men to marry out more often than women because of their numerical supremacy, while Indian and Chinese rates of exogamy should be relatively high for both genders because of their high educational attainements. The actual patterns of intermarriage, however, differ strikingly from these predictions. Blacks (and especially black 


\begin{tabular}{|c|c|c|c|c|c|c|c|}
\hline & \multicolumn{3}{|c|}{ Population aged 16 and above } & \multicolumn{2}{|c|}{$\begin{array}{l}\text { University } \\
\text { degree (\%) }\end{array}$} & \multicolumn{2}{|c|}{$\begin{array}{l}\text { Mean height in } \mathrm{cm} \\
\text { (std dev) }\end{array}$} \\
\hline & $\mathrm{M}$ & $\mathrm{F}$ & $\mathrm{F} / \mathrm{M}$ & M & $\mathrm{F}$ & $\mathrm{M}$ & $\mathrm{F}$ \\
\hline British White & $19,454,964$ & $21,079,873$ & 1.08 & 18.1 & 16.1 & $175.3(7.3)$ & $161.6(6.8)$ \\
\hline Irish White & 305,187 & 345,474 & 1.13 & 23.4 & 25.0 & $174.2(6.8)$ & $161.4(6.5)$ \\
\hline Other White & 562,356 & 664,530 & 1.18 & 19.7 & 21.8 & n.a. & n.a. \\
\hline Mixed & 160,670 & 176,877 & 1.10 & 21.9 & 19.6 & n.a. & n.a. \\
\hline Indian & 400,306 & 410,738 & 1.03 & 29.7 & 20.7 & $170.2(7.0)$ & $156.4(6.3)$ \\
\hline Pakistani & 245,440 & 240,621 & 0.98 & 15.0 & 9.7 & $172.1(7.9)$ & $157.8(6.1)$ \\
\hline Bangladeshi & 87,612 & 86,645 & 0.99 & 11.0 & 4.7 & $167.8(7.2)$ & $154.7(6.2)$ \\
\hline Other Asian & 105,445 & 83,591 & 0.79 & 23.3 & 18.8 & n.a. & n.a. \\
\hline Black Caribbean & 204,503 & 245,995 & 1.20 & 11.3 & 14.6 & $175.2(7.4)$ & $162.8(6.7)$ \\
\hline Black African & 160,291 & 178,536 & 1.11 & 23.6 & 17.4 & $173.5(6.9)$ & $163.0(6.5)$ \\
\hline Other Black & 27,510 & 32,914 & 1.20 & 13.9 & 16.3 & n.a. & n.a. \\
\hline Chinese & 94,282 & 103,863 & 1.10 & 32.9 & 28.8 & $170.8(7.4)$ & $157.9(6.0)$ \\
\hline Any other & 79,464 & 105,442 & 1.33 & 22.6 & 18.5 & n.a. & n.a. \\
\hline Source & \multicolumn{5}{|c|}{ UK Census 2001} & \multicolumn{2}{|c|}{$\begin{array}{l}\text { Health Survey for } \\
\text { England } 2004\end{array}$} \\
\hline
\end{tabular}

Caribbeans) and Chinese in particular seem to defy both conventional wisdom and predictions of theories formulated within sociology and economics.

To help explain these puzzles, the last two columns of Table 5 add data on average height by ethnic groups and gender. Black males are essentially as tall as white men and black women are even slightly taller than white women. The Chinese, Indians, Pakistanis and especially Bangladeshis, in contrast, are relatively short. Again, there is a clear correlation in the distribution of physical stature within ethnic groups and across genders. Given the revealed preferences of men and women concerning their partner's height, anthropometric characteristics therefore promise to be a crucial element of our attempt to make sense of the observed patterns of interethnic marriage.

\subsection{Analysis of intermarriage using the LFS}

We can obtain further and more profound insights on the patterns of inter-ethnic marriage in the UK using at the Labour Force Survey (LFS) household datasets. These are produced each 
spring and autumn from the corresponding quarter's individual-level LFS data. The household datasets include a number of new derived variables at household and family unit level. We use two quarters per year from 2002 up to 2007 (last quarter of 2007 included). In total, therefore, we have 12 quarters. Typically, households will be kept in the survey for five consecutive quarters. We use the most recent wave only for households appearing more than once. The LFS includes important information on socio-economic characteristics of respondents, such as their education level and occupation. There is no information on anthropometric measures though.

We use the variable ethcen15 for ethnicity. The LFS distinguishes 15 different ethnicities. We group some ethnicities together because we presume they are ethnicly/culturally close and because there are few observations in some sub-groups. We group together "Whites" and "Other Whites" and "Black Caribbeans" and "Other Blacks". We define as exogamous any relationship where there is no common ethnic background. Hence, those from mixed races, such as "White and Black African" will be coded as endogamous if they are partnered either with a White or with a Black African. According to this definition, those with a mixed ethnicity can never be in an exogamous relationship with a white partner (the number of mixed race individuals who do not have white ancestry is negligible) and will therefore not be included in the analysis of intermarriage. Since we are interested in explaining ethnic-specific gender asymmetries in marriage rates with whites in particular, we exlude all the other types of exogamous relationships. They represent a very small number of observations anyway.

Table 6 shows the frequency of exogamous relationships by ethnicity and gender (we report both the percentages and the nubmer of observations for each category). We include all relationships where the couples live together, either as spouses or cohabitees (in the latter case, we keep only those who report they are living as a couple).We find a pattern very similar to that obtained with the census data. The proportion of exogamous relationships is very small for Pakistani and Bangladeshi (less than 5\% both for men and women); it is around $8 \%$ for Indian men and women. "Other Asians" and "Chinese" display a much higher 


\begin{tabular}{|c|c|c|c|c|}
\hline & \multicolumn{2}{|l|}{ All } & \multicolumn{2}{|c|}{ UK born or arrived before age 16} \\
\hline & Men & Women & Men & Women \\
\hline \multirow{2}{*}{ Indian } & $8.03 \%$ & 8.09 & $19.46 \%$ & $20.18 \%$ \\
\hline & 235 & 237 & 87 & 110 \\
\hline \multirow{2}{*}{ Pakistani } & 4.80 & $2.38 \%$ & $10.46 \%$ & $3.35 \%$ \\
\hline & 87 & 42 & 32 & 15 \\
\hline \multirow{2}{*}{ Bangladeshi } & $2.37 \%$ & $1.28 \%$ & $19.23 \%$ & $8.97 \%$ \\
\hline & 15 & 8 & 5 & 7 \\
\hline \multirow{2}{*}{ Other Asian } & $17.65 \%$ & $34.99 \%$ & $65.12 \%$ & $54.05 \%$ \\
\hline & 137 & 344 & 28 & 20 \\
\hline \multirow{2}{*}{ Black Caribbean and Other Blacks } & $39.14 \%$ & $26.32 \%$ & $55.16 \%$ & $39.35 \%$ \\
\hline & 411 & 225 & 246 & 146 \\
\hline \multirow{2}{*}{ Black African } & $15.62 \%$ & $10.55 \%$ & $32.43 \%$ & $15.29 \%$ \\
\hline & 144 & 92 & 36 & 13 \\
\hline \multirow{2}{*}{ Chinese } & $16.39 \%$ & $37.80 \%$ & $69.35 \%$ & $75.34 \%$ \\
\hline & 80 & 248 & 43 & 55 \\
\hline
\end{tabular}

propensity for exogamous relationships among women (35\% and $38 \%$ for other Asians and Chinese, respectively) than men (18\% and 16\%). Finally, Black Caribbean men have the largest proportion of intermarriage: almost $40 \%$ live with a white woman. The proportion is much smaller (but still substantial) for Black Caribbean women, 26\% of them are in exogamous relationships. Black Africans show the same gender pattern but the shares are smaller: $16 \%$ of Black African men and $11 \%$ of Black African women are in exogamous relationships. Finally, a very similar pattern appears when looking only at those who were born or grew up in the UK. We see generally higher exogamy rates but their variation across ethnicities and genders differs little. Hence, the ethnic-specific gender asymmetries do not seem to be driven predominantly by imported preferences and/or characteristics.

To get a deeper insight into the determinants of intermarriage, we now turn to investigating who is marrying whom, still using the LFS data. We present simple logistic regressions where the dependent variable distinguishes whether the relationship is exogamous or not and the regressors are ethnicity dummies interacted with dummies for socio-economic characteristics. 


\begin{tabular}{|c|c|c|c|c|c|c|c|c|c|c|c|c|}
\hline \multirow{2}{*}{ Higher educ. } & \multicolumn{2}{|c|}{ Indians } & \multicolumn{2}{|c|}{ Pakistani } & \multicolumn{2}{|c|}{ Chinese } & \multicolumn{2}{|c|}{ Other Asians } & \multicolumn{2}{|c|}{ Black Car. } & \multicolumn{2}{|c|}{ Black Afr. } \\
\hline & $\begin{array}{l}-.02 \\
\end{array}$ & $(.34)$ & .79 & $(.53)$ & 1.74 & $(.72)^{* *}$ & .43 & $(.45)$ & -.39 & $(.30)$ & -.31 & $(.36)$ \\
\hline Univ. degree & $.37^{*}$ & $(.20)$ & .81 & $(.36)^{* *}$ & 1.34 & $(.44) \dagger$ & .60 & $(.31)^{* *}$ & -.30 & $(.26)$ & -.86 & $(.30) \dagger$ \\
\hline Prof./manag. & .31 & $(.21)$ & -.27 & $(.36)$ & .49 & $(.45)$ & -.02 & $(.32)$ & -.19 & $(.22)$ & .44 & $(.30)$ \\
\hline Skilled/n.man. & .31 & $(.27)$ & .15 & $(.45)$ & .88 & $(.55)$ & -.01 & $(.37)$ & -.18 & $(.22)$ & -.15 & $(.32)$ \\
\hline Age band & .05 & $(.05)$ & -.02 & $(.08)$ & .36 & $(.11) \dagger$ & .06 & $(.07)$ & -.02 & $(.05)$ & -.13 & $(.08)^{*}$ \\
\hline Age arrival & -.05 & $(.01) \dagger$ & -.03 & $(.02)$ & -.08 & $(.02) \dagger$ & -.10 & $(.01) \dagger$ & -.05 & $(.01) \dagger$ & -.10 & $(.02) \dagger$ \\
\hline Born in UK & -.17 & $(.41)$ & .13 & $(.67)$ & -.76 & $(.88)$ & -1.40 & $(.83)$ & -.64 & $(.47)$ & -2.97 & $(.77) \dagger$ \\
\hline Constant & -2.04 & $(.65) \dagger$ & -2.31 & $(.95) \dagger$ & -3.91 & $(1.34) \dagger$ & 1.40 & $(.83)$ & 1.19 & $(.72)$ & 3.50 & $(.86) \dagger$ \\
\hline N. Obs. & 2112 & & 1358 & & 355 & & 566 & & 711 & & 689 & \\
\hline
\end{tabular}

The goal is simply to see whether those who are in exogamous relationships are positively or negatively selected along socio-economic attributes and age. We report separate estimates for each gender and ethnicity in Tables 7 and 8. We find a striking pattern among men. Both South and East-Asians, especially Chinese, are all positively selected in terms of education. In contrast, black Carribeans and black Africans are not; in fact, black Africans in exogamous relationships are significantly less likely to be university educated than their endogamous counterparts. Furthermore, exogamous black Carribeans and black Africans tend to be younger than endogamous individuals while the opposite is the case for the Chinese (however, age refers to age at the time of interview and therefore it cannot be used to ascertain whether endogamous and exogamous marriages tend to be concluded at different ages. For women, we find similar positive selection on education among almost all groups, the most notable exception being black Africans. The positive selection appears strongest among Indians. Chinese and other Asian women appear older when in exogamous relationships than endogamous women.

Next, we add the characteristics of whites who intermarry into the analysis. We compute the difference between the ethnic-minority individual's characteristics and the characteristics of their white partner along three dimensions: education, occupation and age. Then we regress this difference on the ethnic-minority individual's own characteristics. Specifically, we estimate ordered probit equations where the dependent variable is either 1 (own characteristics higher), 


\begin{tabular}{|c|c|c|c|c|c|c|c|c|c|c|c|c|}
\hline \multirow{2}{*}{ Higher educ. } & \multicolumn{2}{|c|}{ Indians } & \multicolumn{2}{|c|}{ Pakistani } & \multicolumn{2}{|c|}{ Chinese } & \multicolumn{2}{|c|}{ Other Asians } & \multicolumn{2}{|c|}{ Black Car. } & \multicolumn{2}{|c|}{ Black Afr. } \\
\hline & .50 & $(.28)$ & & & .15 & $(.30)$ & .93 & $(.39)^{* *}$ & .10 & $(.26)$ & -.06 & $(.39)$ \\
\hline Univ. degree & 1.13 & $(.19) \dagger$ & $.85^{*}$ & $(.46)$ & .48 & $(.23)^{* *}$ & .69 & $(.25) \dagger$ & .64 & $(.24)^{* *}$ & -.10 & $(.36)$ \\
\hline Prof./manag. & .62 & $(.22) \dagger$ & 1.79 & $(.55) \dagger$ & .24 & $(.27)$ & .62 & $(.29)^{* *}$ & .07 & $(.26)$ & .40 & $(.41)$ \\
\hline Skilled/n.man. & .89 & $(.19) \dagger$ & 2.22 & $(.47) \dagger$ & -.44 & $(.21)^{* *}$ & 1.19 & $(.27) \dagger$ & -.38 & $(.21)$ & .36 & $(.32)$ \\
\hline Age bands & .08 & $(.05)$ & .10 & $(.11)$ & .09 & $(.04)^{* *}$ & .15 & $(.06) \dagger$ & -.05 & $(.06)$ & .11 & $(.08)$ \\
\hline Age arrival & -.06 & $(.01) \dagger$ & -.05 & $(.02)^{* *}$ & -.01 & $(.01)$ & .00 & $(.01)$ & -.02 & $(.01)$ & -.05 & $(.02)^{* *}$ \\
\hline Born in UK & -.85 & $(.37)^{* *}$ & -1.69 & $(.75)^{* *}$ & .21 & $(.53)$ & 1.62 & $(.55) \dagger$ & -.09 & $(.51)$ & -1.63 & $(.85)^{*}$ \\
\hline Constant & -2.14 & $(.57) \dagger$ & -3.58 & $(1.08)$ & -.87 & $(.46)$ & -2.53 & $(.61) \dagger$ & .01 & $(.74)$ & -1.19 & $(.82)$ \\
\hline N. Obs. & 2293 & & 1416 & & 750 & & 509 & & 636 & & 699 & \\
\hline
\end{tabular}

0 (own characteristics equal) or -1 (own characteristics lower). ${ }^{8}$ The results are reported in Table 9. We find no systematic differences in the characteristics of white female partners, conditioning on the etnic-minority men's characteristics (columns denoted 'men'). White male partners differ, however, depending on whom they marry. Indian, Chinese, other Asian and also black African women tend to marry white men who are more educated than them whereas the reverse holds for black Caribbean women (the reference category). And black Caribbean women tend to be significantly younger than their white partners, more so than the women belonging to other ethnic minorities.

In summary, we find that interracial marriages involve mostly men and women who are more educated than endogamous individuals. The main exceptions to this pattern are black men, and white men who marry black Caribbean women.

\section{The "male-superior" norm and intermarriage}

Our argument about the implications of the "male-superior" norm for inter-ethnic marriage rests on the observation, which we made above, that socio-economic and physical attributes tend to be correlated across genders within the same ethnicity. For example, Asian men and women alike are shorter than whites on average while black men and women are both relatively

\footnotetext{
${ }^{8}$ Education and occupation are measured by categorical variables, whereby higher values indicate higher education or skill level. Age is reported also as a categorical variable (age bands) rather than the actual value.
} 


\begin{tabular}{|c|c|c|c|c|c|c|c|c|c|c|c|c|}
\hline \multicolumn{13}{|c|}{ Ordered probit regressions (all sample) } \\
\hline & \multicolumn{4}{|c|}{ Education differential } & \multicolumn{4}{|c|}{ Occupation differential } & \multicolumn{4}{|c|}{ Age differential } \\
\hline \multirow{2}{*}{ Black Carib. } & \multicolumn{2}{|c|}{ Men } & \multicolumn{2}{|c|}{ Women } & \multicolumn{2}{|c|}{ Men } & \multicolumn{2}{|c|}{ Women } & \multicolumn{2}{|c|}{ Men } & \multicolumn{2}{|c|}{ Women } \\
\hline & - & - & - & - & - & - & - & - & - & - & - & - \\
\hline Indians & -.11 & $(.13)$ & -.25 & $(.12)^{* *}$ & -.05 & $(.16)$ & -.24 & $(.14)^{*}$ & .13 & $(.12)$ & .20 & $(.12)^{* *}$ \\
\hline Pakistani & .11 & $(.17)$ & -.09 & $(.22)$ & -.06 & $(.25)$ & .10 & $(.26)$ & .18 & $(.16)$ & .28 & $(.21)$ \\
\hline Bangladeshi & -.32 & $(.41)$ & -.22 & $(.54)$ & -.10 & $(.49)$ & -.61 & $(.58)$ & .17 & $(.37)$ & -.49 & $(.49)$ \\
\hline Chinese & .25 & $(.18)$ & -.53 & $(.12) \dagger$ & -.18 & $(.21)$ & -.16 & $(.15)$ & -.11 & $(.17)$ & .38 & $(.12) \dagger$ \\
\hline Other Asians & -.02 & $(.14)$ & -.28 & $(.11)^{* *}$ & .15 & $(.18)$ & -.15 & $(.14)$ & -.01 & $(.14)$ & .35 & $(.11) \dagger$ \\
\hline Black Afr. & -.03 & $(.14)$ & -.33 & $(.17)^{*}$ & .26 & $(.17)$ & .19 & $(.21)$ & -.05 & $(.13)$ & .81 & $(.17) \dagger$ \\
\hline N. Obs & 776 & & 995 & & 538 & & 669 & & 795 & & 1031 & \\
\hline Pseudo R-sqrd & .23 & & .25 & & .20 & & .10 & & .03 & & .05 & \\
\hline
\end{tabular}

tall. Homogamic preferences (preferences for 'likes') would imply that men and women of the same ethnicity should fare similarly in the white marriage market. As the data reviewed in Tables 1 and 2 demonstrate, this is clearly not the case. Therefore, given that we observe large gender-specific asymmetries in intermarriage rates for some ethnicities, the "male-superior" norm offers a more promising an explanation than homogamic preferences.

We construct a measure of the proportion of acceptable partners in the white and ownethnicity populations, respectively, given the individual's own attribute. We consider two attributes, height and education, because of the survey evidence cited above (Higgins et al., 2002) concerning attitudes that men and females have with respect to their potential partners' characteristics. Acceptable partners are those who satisfy the rule "male's attribute is at least as high as the female's attribute". Suppose, for simplicity, that $x$ is the only attribute that matters for selecting a future spouse. Denote by $F_{j}(x)$ the corresponding distribution function of attribute $x$ in the female population of ethnicity $j$ and $G_{j}(x)$ the distribution function of attribute $x$ in the male population of ethnicity $j$. For example, suppose that people only care about height and have a preference of the "husband taller than wife" type. Denote by $F_{k}(x)$ 
and $G_{k}(x)$ the respective distributions of the attribute in the female and male populations of ethnicity $k$. Then, the proportion of acceptable mates of ethnicity $j$ for a woman of attribute $x_{f}$ is equal to: $\left(1-G_{j}\left(x_{f}\right)\right)$ and the proportion of acceptable mates of ethnicity $j$ for a man with attribute $x_{m}$ is $F_{j}\left(x_{m}\right)$.If we have individual information on $x$, we can calculate individualspecific shares of acceptable partners. For women, the proportion of acceptable men with ethnicity $j$, conditional on ethnicity $k$ equals:

$$
\int\left(1-G_{j}(x)\right) f_{k}(x) d x
$$

and for men:

$$
\int\left(F_{j}(x)\right) g_{k}(x) d x
$$

Note that the following implications hold, conditionally on gender groups within a given ethnicity being of identical size:

- When $F_{i}(x)$ and $G_{i}(x)$ stochastically first-order dominate $F_{j}(x)$ and $G_{j}(x)$, respectively, the probability that groups $i$ and $j$ intermarry should be higher for females of ethnic group $i$ than males.of group $i$, while the reverse is true for group $j$.

- Among the populations with relatively low mean value of $x$, the average value of $x$ should be higher for those intermarrying with whites than for those in homogamous marriages.

\subsection{Predictions based on the UK census and Health Survey for England}

In line with the preceding discussion, we first calculate the fraction of acceptable partners for each ethnic group, with reference to height and education. The fractions of acceptable partners are computed using aggregate data: the 2001 UK census for education and the Health Survey for England (2004) for height. ${ }^{9}$ Table 10 shows the results. We find that black Caribbean men do indeed have a larger share of acceptable partners among whites than do black Caribbean

\footnotetext{
${ }^{9}$ Fraction of acceptable partners with respect to education is computed at the regional level (12 regions of the UK) while the corresponding fraction with respect to height is computed at the national level only due to lack of regional data.
} 


\begin{tabular}{lllllll}
\hline \multicolumn{7}{l}{ Table 10:.Percentage of acceptable partners (\%) } \\
\hline \multicolumn{7}{l}{ Height } \\
\hline Own ethnicity & White women & White men & Own ethnicity & White women & White men \\
\hline Whites & 92 & & & 61.7 & & 62.0 \\
Black Caribbeans & 89.3 & 91.5 & 89.7 & 51.0 & 53.5 & 61.0 \\
Black Africans & 86.6 & 89.5 & 89.6 & 65.5 & 59.5 & 65.0 \\
Indians & 92.9 & 81.7 & 97.5 & 62.7 & 61.1 & 64.2 \\
Pakistani & 92.4 & 84.8 & 96.7 & 66.2 & 47.5 & 75.5 \\
Bangladeshi & 91.6 & 74.2 & 98.4 & 72.3 & 39.3 & 82.8 \\
Chinese & 91.2 & 82.6 & 96.7 & 63.6 & 60.2 & 62.2 \\
\hline
\end{tabular}

women: 91.5 percent and 89.7 percent, respectively. The opposite is true for Asians (and substantially so): for women, 96-99 percent of white men are acceptable whereas only 7485 of white women are acceptable for Asian men. Black African men and women, on the othe hand, face relatively similar shares of acceptable partners among whites. If we calculate the proportion of acceptable partners based on education, we find very different predictions. Among all ethnic groups, women have better prospects to outmarry than men. Furthermore, the fraction of acceptable partners is highest for the Chinese and Indians. Hence, if a "malesuperior" norm with respect to education was important, we should expect these two ethnic groups to have the highest propensity to intermarry with whites. As we show above, this is not the case. Thus, already based on this simple exercise alone, height indeed does a much better job at explaining ethnic-specific gender asymmetries than education.

\subsection{Evidence based on the Milennium Cohort Study}

We now present evidence based on micro data using the Milennium Cohort Study (MCS). The MCS is based on a sample of babies born in the year 2000. It reports information on parents of around 18,000 babies, while oversampling ethnic minorities. The main respondent is typically a woman (in $99.9 \%$ of the cases). Crucially, the data include information on ethnicity of the main respondent and the main respondent's partner .We have data on 13,066 couples with ethnicity information on both the respondent and partner, where at least one of the partners is white. These include 414 mixed couples (if we considered also mixed marriages where none 
of the partners is white, the number of mixed couples would increase to 560). 240 of these couples involve a white woman and a non-white man, 174 involve a white man and non-white woman.

We examine how much of the ethnic-specific gender differences in propensities to outmarry can be explained with asymmetric preferences. We introduce the proportions of acceptable partners as additional controls. We want to see whether including them helps reduce the gender differences in outmarriage across ethnicities. The results are shown in Table 11. The first column only includes ethnicity and gender, interacted. The results confirm what we have found before: Black caribbean women are substantially less likely to outmarry than women from other ethnicities, in particular Indians and Chinese. In column (2), we add the proportion of acceptable partners based on the respondent's height while in column (3) we augment the regression with the proportion of acceptable partners based on the respondent's education. The results are quite striking. While controlling for acceptable partners with respect to the education dimension does not help explain intermarriage, controlling for the proportions of acceptable partners based on height makes an important difference: the ethnic differences in outmarriage rates shrink when we include the proportion of acceptable partners with respect to height while they remain almost identical when we control for acceptable partners based on education. These results suggest that height does indeed help explain part of the puzzle of gender specific differences in intermarriage rates across ethnicities. Moreover, the fraction of acceptable partners based on the height rule predicts outmarriage in the direction we would expect: the larger the share of acceptable white partners and the lower the share of acceptable partners within one's own ethnicity, the higher the probability of outmarrying. On the other hand, the proportions of acceptable partners based on education have estimated coefficients close to 0 and are insignificant.

As the next step, we compare mean heights of those who intermarry with those who marry an individual of their own ethnicity. A straightforward implication of the "height-rule" is that among ethnic groups that are on average shorter, those who intermarry with whites should 


\begin{tabular}{|c|c|c|c|c|c|c|}
\hline $\begin{array}{l}\text { Marginal effects } \\
\text { Marginal effects }\end{array}$ & (1) & & (2) & & (3) & \\
\hline Black Caribbeans & - & & - & & - & \\
\hline Indian & -.15 & $(.04)^{* * *}$ & -.09 & $(.05)^{* *}$ & -.15 & $(.04)^{* * *}$ \\
\hline Pakistani & -.23 & $(.05)^{* * *}$ & -.20 & $(.04)^{* * *}$ & -.23 & $(.05)^{* * *}$ \\
\hline Bangladeshi & -.12 & $(.02)^{* * *}$ & -.09 & $(.02)^{* * *}$ & -.12 & $(.02)^{* * *}$ \\
\hline Other Asian & -.12 & $(.02)^{* * *}$ & -.11 & $(.01)^{* * *}$ & -.12 & $(.02)^{* * *}$ \\
\hline Black Africans & -.04 & $(.06)$ & -.03 & $(.07)$ & -.05 & $(.06)$ \\
\hline Chinese & -.09 & $(.01)^{* * *}$ & -.08 & $(.01)^{* * *}$ & -.09 & $(.01)^{* * *}$ \\
\hline Female & -.08 & $(.04)^{* *}$ & -.07 & $(.03)^{* *}$ & -.08 & $(.04)^{* *}$ \\
\hline Indian x Female & .04 & $(.04)$ & -.02 & $(.05)$ & .04 & $(.05)$ \\
\hline Pakistani x Female & .08 & $(.05)^{*}$ & .04 & $(.05)$ & .08 & $(.06)$ \\
\hline Bangladeshi x Female & .06 & $(.06)$ & -.04 & $(.07)$ & .06 & $(.08)$ \\
\hline Other Asian x Female & .20 & $(.06)^{* * *}$ & .13 & $(.06)^{* *}$ & .20 & $(.06)^{* * *}$ \\
\hline Black African x Female & -.09 & $(.07)$ & -.10 & $(.07)$ & -.09 & $(.08)$ \\
\hline Chinese x Female & .20 & $(.08)^{* *}$ & .13 & $(.08)$ & .20 & $(.08)^{* * *}$ \\
\hline Acceptable white partners (height) & & & .35 & $(.12)^{* * *}$ & & \\
\hline Acceptable partners own ethnicity (height) & & & -.32 & $(.11)^{* * *}$ & & \\
\hline Acceptable white partners (education) & & & & & -.01 & $(.01)$ \\
\hline Acceptable partners own ethnicity (education) & & & & & .00 & $(.02)$ \\
\hline Share own ethnicity & -2.98 & $(.40)^{* * *}$ & -2.89 & $(.39)^{* * *}$ & -2.99 & $(.40)^{* * *}$ \\
\hline N. obs. & 1362 & & 1362 & & 1362 & 1362 \\
\hline Pseudo R-squared & .22 & & .24 & & .20 & \\
\hline
\end{tabular}




\begin{tabular}{lllll}
\hline \multicolumn{5}{l}{ Table 12: Mean height of women from ethnic minorities } \\
Ethnicity & All & Endogamous & Exogamous & Difference \\
\hline Black African & 163.0 & 165.1 & 165.8 & +0.7 \\
Black Caribbean & 162.8 & 164.4 & 167.6 & +2.8 \\
Bangladeshi & 154.7 & 156.1 & 162.6 & +6.5 \\
Pakistani & 157.8 & 160.6 & 160.9 & +0.3 \\
Indian & 156.4 & 159.2 & 161.3 & +2.1 \\
Chinese & 157.8 & 161.1 & 160.7 & -0.4 \\
\hline
\end{tabular}

\begin{tabular}{lllll}
\hline \multicolumn{5}{l}{ Table 13: Mean height of men from ethnic minorities $(\mathrm{cm})$} \\
Ethnicity & All & Endogamous & Exogamous & Difference \\
\hline Black African & 173.5 & 176.1 & 177.2 & +1.1 \\
Black Caribbean & 175.2 & 176.3 & 176.0 & -0.3 \\
Bangladeshi & 167.8 & 168.7 & 171.7 & +3.0 \\
Pakistani & 172.1 & 174.6 & 173.8 & -0.8 \\
Indian & 170.2 & 173.5 & 175.6 & +2.1 \\
Chinese & 170.8 & 171.2 & 172.7 & +1.5 \\
\hline
\end{tabular}

tend to be taller on average than those who marry within their own ethnicity. Moreover, this should be true for both men and women.

Tables 12-13 present mean heights of men and women, per ethnicity and type of relationship. ${ }^{10}$ Let us look at women first. The positive selection into exogamous relationships is observed for all ethnicities, with the exception of Chinese. The pattern is especially striking for Bangladeshi women: those in exogamous relationships are on average $6.5 \mathrm{~cm}$ taller than their endogamous counterparts. Exogamous black Caribbean and Indian women also stand out by by being taller than endogamous women. Moving on to men (Table 13), we again see positive selection according to height into exogamous marriage. The difference is largest for Bangladeshi men although the difference is not as striking as for Bangladeshi women. Exogamous Indian and Chinese men also tend to be taller. Exogamous and endogamous black Caribbeans are little different - which is not surprising given that black Caribbean men are on average the same height as whites.

Of course, these differences could be driven by the correlation between height and socio-

\footnotetext{
${ }^{10}$ The figures in column denoted as 'all' refer to the mean height for all individuals, including those who are single, based on the Health Survey for England rather than the Milennium Cohort Survey.
} 


\begin{tabular}{|c|c|c|c|c|c|c|c|c|}
\hline \multicolumn{5}{|c|}{$\begin{array}{l}\text { Table 14: Height, ethnicity and intermarriage }(\mathrm{cm}) \\
\text { Men }\end{array}$} & \multicolumn{4}{|c|}{ Women } \\
\hline & (1) & & (2) & & (3) & & (4) & \\
\hline Intermarry & 1.32 & $(.81)$ & 1.38 & $(.81)^{*}$ & 2.45 & $(.99)^{* *}$ & 2.54 & $(.99)^{* *}$ \\
\hline Black Caribbean & - & & - & & - & & & \\
\hline Indian & -1.33 & $(.94)$ & -1.44 & $(.96)$ & -4.32 & $(.95) \dagger$ & -4.98 & $(.97) \dagger$ \\
\hline Pakistani & -.39 & $(.97)$ & -.56 & (1.01) & -3.34 & $(.97) \dagger$ & -3.93 & $(1.01) \dagger$ \\
\hline Bangladeshi & -5.51 & $(1.13) \dagger$ & -5.66 & $(1.15) \dagger$ & -8.75 & $(1.14) \dagger$ & -9.42 & $(1.19) \dagger$ \\
\hline Chinese & -3.70 & $(1.85)^{* *}$ & -3.86 & $(1.86)^{* *}$ & -4.35 & $(1.63) \dagger$ & -4.85 & $(1.61) \dagger$ \\
\hline Other Asian & -2.46 & $(1.33)^{*}$ & -2.28 & $(1.34)^{*}$ & -4.86 & $(1.26) \dagger$ & -5.25 & $(1.26) \dagger$ \\
\hline Black African & 1.01 & $(1.08)$ & 1.05 & $(.93)$ & 1.60 & $(1.13)$ & 1.13 & $(1.14)$ \\
\hline $\begin{array}{l}\text { Controls for age, education } \\
\text { and occupation }\end{array}$ & No & & Yes & & No & & Yes & \\
\hline $\mathrm{N}$ & 822 & & 822 & & 833 & & 833 & \\
\hline R-squared & .07 & & .07 & & .13 & & .13 & \\
\hline
\end{tabular}

economic characteristics, since we have shown that, for example, Asians who intermarry tend to be more educated than those who do not. To account for this possibility, in Table 14, we regress height on ethnicity and a dummy variable distinguishing whether the respondent is in an exogamous relationship (with a white person) or not. These regressions are reported in columns (1) and (3) for men and women, respectively. On average (across all ethnic groups), exogamous men are taller by $1.3 \mathrm{~cm}$ than endogamous men while for women the difference is as $2.5 \mathrm{~cm}$. In columns (2) and (4), we add socio-economic characteristics as additional controls. However, rather than diminishing the difference between endogamous and exogamous individual, the positive selection on height appears just as pronounced if not even more pronounced once we control for socio-econonomic attributes.

In Tables 15-16, finally, we present similar figures on mean heights of whites depending on their spouse ethnicity. The general pattern is again perfectly in line with what we would expect. In particular, white women married to black Africans and especially black Caribbeans tend to be taller than endogamous white women while those married to Chinese and Indian men tend to be shorter. White men married to black Africans are taller than endogamous whites (although we do not observe a similar pattern for those married to black Caribbean 


\begin{tabular}{lllll}
\hline \multicolumn{5}{l}{ Table 15: Mean height of white women $(\mathrm{cm})$} \\
Spouse's ethnicity & All & Endogamous & Exogamous & Difference \\
\hline Black African & 161.4 & 164.2 & 165.3 & +1.1 \\
Black Caribbean & 161.4 & 164.2 & 166.6 & +2.4 \\
Bangladeshi & 161.4 & 164.2 & 164.8 & +0.6 \\
Pakistani & 161.4 & 164.2 & 164.2 & +0.0 \\
Indian & 161.4 & 164.2 & 161.1 & -3.1 \\
Chinese & 161.4 & 164.2 & 162.1 & -2.1 \\
\hline \multicolumn{5}{l}{ Table 16: Mean height of white men (cm) } \\
Spouse's ethnicity & All & Endogamous & Exogamous & Difference \\
\hline Black African & 175.3 & 178.4 & 184.6 & +6.2 \\
Black Caribbean & 175.3 & 178.4 & 177.3 & -1.1 \\
Bangladeshi & 175.3 & 178.4 & 171.7 & -6.7 \\
Pakistani & 175.3 & 178.4 & 177.1 & -1.3 \\
Indian & 175.3 & 178.4 & 176.7 & -1.7 \\
Chinese & 175.3 & 178.4 & 178.3 & -0.1 \\
\hline
\end{tabular}

women) and those married to Bangladeshi women are substantially shorter.

\section{Conclusion}

We investigate the determinants of ethnic-specific gender asymmetries in intermarriage rates. Both in the UK and in the US, we observe a larger propensity to intermarry with whites among black men than black women, while the reverse is true for Asians, in particular Chinese. We show that this pattern cannot be explained by socio-economic attributes such as education or occupation. Using data from the Labour Force Survey for the period 2002-2007, we show that intermarriage occurs mainly among more educated people, except for black men marrying whites and white men marrying black Caribbean women. These results suggest there are other factors besides socio-economic characteristics that affect the relative success of the various ethnic groups in the white marriage market.

We show that a simple "husband taller than wife" behavioral rule helps explain these gender asymmetries. On average, blacks are taller than Asians and are of similar height as whites. This rule implies that black males should fare better in the white marriage market than East 
and South Asian men while the opposite should hold for black and Asian women. We present empirical evidence in support of this hypothesis using data from the Health Survey for England (2004) and the Millenium Cohort Study (2000), which shows that the height preference rule is indeed a very good predictor of the probability of intermarrying with whites. In contrast, a similarly formulated preference rule based on education holds little explanatory power with respect to the patterns of interethnic marriage.

These results deepen our understanding of social and cultural integration of ethnic minorities in Western societies. Furthermore, they also point out a previously unrecognized implication of large immigration flows: they can potentially alter the sex ratio on the marriage market - and in turn the bargaining power of the two genders - even if their gender composition is roughly balanced. For example, a large inflow of East Asian (and Chinese) immigrants to the UK or the US will effectively increase the marriage-market opportunities, and the bargaining power, of white men relatively to white women, even if the influx is balanced with respect to genders. ${ }^{11}$ And, rather ironically, the relaxation of laws or social norms against interethnic marriages ${ }^{12}$ may implicitly increase the relative bargaining power of one gender in comparison to the other; and may even disadvantage some ethnic-minority individuals (in particular black women) in the marriage market. It would be worthwhile to investigate what are the implications in terms of household behaviour and distribution of resources within the household.

\section{References}

[1] Akerlof, G. and R.E. Kranton (2000). "Economics and Identity," Quarterly Journal of Economics (August), 715-753.

\footnotetext{
${ }^{11}$ Future research will show whether the large influx of Polish and other Eastern European migrants to the UK will have also have an asymmetric effect on the UK marriage market.

${ }^{12}$ The most notable instance of this is the repeal of antimiscegenation laws in the US following the Supreme Court ruling on Loving vs Virginia.
} 
[2] Becker, G. (1973). "A Theory of Marriage: Part I," Journal of Political Economy 81 (4), 813-846.

[3] Becker, G. (1974). "A Theory of Marriage: Part II," Journal of Political Economy 82 (2), S11-S26.

[4] Belot, M. and M. Francesconi (2006), "Can Anyone be 'The One'? Evidence on Mate Selection from Speed Dating," CEPR Discussion Paper No. 5926, Centre for Economic Policy Research, London.

[5] Bisin, A., G. Topa and T. Verdier (2004), "Religious Intermarriage and Socialization in the United States," Journal of Political Economy 112 (3), 615-664.

[6] Buunk, A.P., J.H. Park, R. Zurriaga, L. Klavina, and K. Massar (2008). "Height Predicts Jealousy Differntly for Men and Women," Evolution and Human Behavior 29, 133-139.

[7] Fisman, R., S. Iyengar, E. Kamenica and I. Simonson, "Gender Differences in Mate Selection: Evidence from a Speed Dating Experiment," Quarterly Journal of Economics (May 2006), 673-697.

[8] Fisman, R., S. Iyengar, E. Kamenica and I. Simonson (2008), "Racial Preferences in Dating," Review of Economic Studies 75, 117-32.

[9] Fryer, R. (2007), "Guess Who's Been Coming for Dinner? Trends in Interracial Marriage over the 20th Century," Journal of Economic Perspectives 21(2), 71-90.

[10] Glowsky, D. (2007), "Why Do German Men Marry Women from Less Developed Countries? An Analysis of Transnational Partner Search Based on the German Socio-Economic Panel," SOEP Papers on Multidiscriplinary Panel Data Research No. 61, DIW Berlin.

[11] Higgins, L., M. Zheng, Y. Liu and C.H. Sun (2002), "Attitudes to Marriage and Sexual Behaviors: A Survey of Gender and Culture Differences in China and the United Kingdom," Sex Roles 3/4, 75-89. 
[12] Hirtsch, G., A. Hortaçsu and D. Ariely (2006). "What Makes You Click? Mate Preferences in Online Dating," MIT Sloan Working paper 4603-06.

[13] Hirtsch, G., A. Hortaçsu and D. Ariely (2008). "Matching and Sorting in Online Dating," University of Chicago, mimeo.

[14] Jacobs, J.A. and Labov T.G. (2002), "Gender Differentials among Sixteen Race and Ethnic Groups," Sociological Forum 17(4), 621-46.

[15] Kalmijn, M. (1998), "Intermarriage and Homogamy: Causes, Patterns, Trends," Annual Review of Sociology 24, 395-421.

[16] Kantarevic, J. (2004), "Interethnic marriages and Economic Assimilation of Immigrants," IZA Discussion Paper 1142.

[17] Merton, R.K. (1941). "Intermarriage and the Social Structure: Fact and Theory," Psychiatry 4, 361-374.

[18] Meng, X. and R. Gregory (2005), "Intermarriage and the Economic Assimilation of Immigrants," Journal of Labor Economics 23(1), 135-76.

[19] Meng, X. and D. Meurs (2006), "Intermarriage, Language and Economic Assimilation Process: A Case Study of France," IZA Discussion Paper 2461.

[20] Merton, R. (1941), "Intermarriage and the Social Structure: Fact and Theory," Psychiatry $4,361-74$.

[21] Sailer, S. (1997), "Is Love Colorblind?," http://www.isteve.com/IsLoveColorblind.htm.

[22] Steckel, R. (1995). "Stature and Standard of Living," Journal of Economic Literature 33 (4), 1903-1940. 
[23] Van Ours, J. and J. Veenman (2008), "How Interethnic Marriages Affect the Educational Attainment of Children: Evidence from a Natural Experiment," IZA Discussion Paper 3308 . 


\section{DAVIDSON INSTITUTE WORKING PAPER SERIES - Most Recent Papers}

The entire Working Paper Series may be downloaded free of charge at: www.wdi.umich.edu

CURRENT AS OF 2/13/09

\begin{tabular}{|c|c|c|}
\hline Publication & Authors & Date \\
\hline $\begin{array}{l}\text { No. 950: Anthropometry of Love } \\
\text { Height and Gender Asymmetries in Interethnic Marriages }\end{array}$ & Michèle Belot and Jan Fidrmuc & \\
\hline No. 949: Is THE COST OF LIVING IN RUSSIA REALLY THAT LOW? & Konstantin Gluschenko & Dec 2008 \\
\hline $\begin{array}{l}\text { No. 948: Banking Market Liberalization and Bank Performance: the Role } \\
\text { of Entry Modes }\end{array}$ & Ngoc-Anh Vo Thi & Jan 2009 \\
\hline $\begin{array}{l}\text { No. 947: The Monetary Union: The Decade Ahead. } \\
\text { The Case of Non-Member States }\end{array}$ & Daniel Daianu and Laurian Lungu & Jan 2009 \\
\hline No. 946: Currency Substitution: A Case Of Kazakhstan (2000:1-2007:12) & $\begin{array}{l}\text { Mesut Yilmaz, Yessengali } \\
\text { Oskenbayev \& Kanat Abdulla }\end{array}$ & Jan 2009 \\
\hline $\begin{array}{l}\text { No. 945: Determinants Of Pollution Abatement And Control Expenditure: } \\
\text { Evidence From Romania }\end{array}$ & $\begin{array}{l}\text { Guglielmo Caporale, Christophe } \\
\text { Rault, Robert Sova \& Anamaria } \\
\text { Sova }\end{array}$ & Jan 2009 \\
\hline $\begin{array}{l}\text { No. 944: Bootstrap panel Granger-causality between government } \\
\text { spending and revenue in the EU }\end{array}$ & $\begin{array}{l}\text { Antonio Afonso and Christophe } \\
\text { Rault }\end{array}$ & Jan 2009 \\
\hline No. 943: Regional Determinants of FDI Distribution in Poland & $\begin{array}{l}\text { Agnieszka Chidlow and Stephen } \\
\text { Young }\end{array}$ & Nov 2008 \\
\hline No. 942: Structural Reform and Firm Exports & $\begin{array}{l}\text { Alvaro Cuervo-Cazurra \& Luis } \\
\text { Alfonso Dau }\end{array}$ & Sept 2008 \\
\hline $\begin{array}{l}\text { No. 941: Exploring The Relationship Between Military Spending \& } \\
\text { Human Rights Performance In South Asia }\end{array}$ & $\begin{array}{l}\text { Krishna Chaitanya, Vadlamannati } \\
\text { and K K Shakya Lahiru Pathmalal }\end{array}$ & Oct 2008 \\
\hline $\begin{array}{l}\text { No. 940: Structural Reform And Firm Profitability In Developing } \\
\text { Countries }\end{array}$ & $\begin{array}{l}\text { Alvaro Cuervo-Cazurra \& Luis } \\
\text { Alfonso Dau }\end{array}$ & July 2008 \\
\hline $\begin{array}{l}\text { No. 939: Does Timing Of Elections Instigate Riots? } \\
\text { A Subnational Study Of } 16 \text { Indian States, } 1958 \text { - } 2004\end{array}$ & Krishna Chaitanya Vadlamannati & Oct 2008 \\
\hline $\begin{array}{l}\text { No. 938: Price Setting And Market Structure: An Empirical Analysis Of } \\
\text { Micro Data }\end{array}$ & Fabrizio Coricelli \& Roman Horvath & Sept 2008 \\
\hline $\begin{array}{l}\text { No. 937: Inflation Differentials in EU New Member States: An Empirical } \\
\text { Evidence }\end{array}$ & Roman Horvath \& Kamila Koprnicka & Oct 2008 \\
\hline $\begin{array}{l}\text { No. 936: Market Reforms and Growth in Post-socialist Economies: } \\
\text { Evidence from Panel Cointegration and Equilibrium Correction Model }\end{array}$ & Igor Pelipas and Alexander Chubrik & Sept 2008 \\
\hline $\begin{array}{l}\text { No. 935: Derivatives trading and the volume-volatility link in the Indian } \\
\text { Stock Market }\end{array}$ & $\begin{array}{l}\text { S. Bhaumiky, M. Karanasosy and } \\
\text { A. Kartsaklas }\end{array}$ & April 2008 \\
\hline $\begin{array}{l}\text { No. 934: Yuan Real Exchange Rate Undervaluation, 1997-2006. How } \\
\text { Much, How Often? Not Much, Not Often }\end{array}$ & $\begin{array}{l}\text { Jeff Chen, Wende Deng \& David } \\
\text { Kemme }\end{array}$ & Aug 2008 \\
\hline $\begin{array}{l}\text { No. 933: How Important Are Foreign Shocks in Small Open Economy? } \\
\text { The Case of Slovakia }\end{array}$ & $\begin{array}{l}\text { Roman Horváth and Marek } \\
\text { Rusnák }\end{array}$ & Sept 2008 \\
\hline $\begin{array}{l}\text { No. 932: Estimating Poverty for Indigenous Groups in Chile } \\
\text { by Matching Census and Survey Data }\end{array}$ & $\begin{array}{l}\text { Claudio A. Agostini, Philip H. } \\
\text { Brown, and Andrei Roman }\end{array}$ & Aug 2008 \\
\hline $\begin{array}{l}\text { No. 931: Is There Electoral Cycles In Globalization Process? Evidence } \\
\text { From } 78 \text { Democratic Countries, } 1975 \text { - } 2006\end{array}$ & Krishna Chaitanya Vadlamannati & Sept 2008 \\
\hline No. 930: Lobbying, Corruption \& Other Banes & $\begin{array}{l}\text { Nauro Campos \& Francesco } \\
\text { Giovannoni }\end{array}$ & Sept 2008 \\
\hline $\begin{array}{l}\text { No. 929: Do Elections Slow Down Economic Globalization Process In } \\
\text { India? It's Politics Stupid! }\end{array}$ & Krishna C Vadlamannati & Aug 2008 \\
\hline $\begin{array}{l}\text { No. 928: Impact Of Institutional Quality On Human Rights Abuses } \\
\text { In Transition Economies }\end{array}$ & $\begin{array}{l}\text { Krishna C Vadlamannati \& Artur } \\
\text { Tamazian }\end{array}$ & July 2008 \\
\hline $\begin{array}{l}\text { No. 927: Do Choice \& Speed Of Reforms Matter For } \\
\text { Human Rights During Transition? }\end{array}$ & Krishna Chaitanya Vadlamannati & July 2008 \\
\hline
\end{tabular}

